\title{
Fatty acid profile and proliferation of bovine blood mononuclear cells after conjugated linoleic acid supplementation
}

\author{
Lydia Renner ${ }^{1}$, Julia Pappritz ${ }^{1}$, Ronny Kramer $^{2}$, Susanne Kersten ${ }^{1 *}$, Gerhard Jahreis ${ }^{2}$ and Sven Dänicke ${ }^{1}$
}

\begin{abstract}
Background: Conjugated linoleic acids (CLA) are in focus of dairy cattle research because of its milk fat reducing effects. Little is known about the impact of CLA on immune function in dairy cows. Therefore, in the present study we investigated the effects of a long term supplementation of dairy cows with CLA on the fatty acid profile of peripheral blood mononuclear cells (PBMC) and their proliferation ex vivo.

Results: The supplementation of dairy cows with either $100 \mathrm{~g} / \mathrm{d}$ of a control fat preparation (CON, n=15), $50 \mathrm{~g} / \mathrm{d}$ of the control fat preparation and $50 \mathrm{~g} / \mathrm{d}$ CLA supplement - containing 12.0\% cis-9, trans-11 and 11.9\% trans-10, cis-12 CLA of total fatty acid methyl esters - (CLA-50, $\mathrm{n}=15)$ or $100 \mathrm{~g} / \mathrm{d}$ of the CLA supplement (CLA-100, $\mathrm{n}=16$ ) did not influence the major fatty acids (C18:0, C16:0, cis-9 C18:1, cis-9, cis-12 C18:2, cis-5, cis-8, cis-11, cis-14 C20:4) in the lipid fraction of PBMC. The proportion of trans-10, cis-12 CLA of total fatty acids was increased in both CLA supplemented groups, but there was no effect on the cis-9, trans-11 isomer. Furthermore, the proportion of trans9 C18:1 and cis-12 C24:1 was reduced in the CLA-100 group. The mitogen stimulated cell proliferation was not influenced by CLA feeding.
\end{abstract}

Conclusion: CLA supplementation influenced the FA profile of some minor FA in PBMC, but these changes did not lead to differences in the mitogen induced activation of the cells.

Keywords: CLA, Dairy cow, Peripheral blood mononuclear cells, Cell proliferation, Fatty acid profile

\section{Background}

Conjugated linoleic acids (CLA) are a group of positional isomers of linoleic acid, which are characterized by conjugated double bonds. They are intermediate products in the biohydrogenation of unsaturated fatty acids (FA) by microorganisms in the rumen [1]. Additionally, it is reported, that CLA originate from endogenous synthesis in tissues like the mammary gland of ruminants [2]. Several positive physiological effects are reported for CLA, like anticarcinogenic (e.g. reviewed by $[3,4]$ ), antiatherogenic [5] and immunomodulatory [6] properties. In general, dietary FA are able to influence the function of immune cells due to different mechanisms, which include alteration of the membrane, changes in signal

\footnotetext{
* Correspondence: susanne.kersten@fli.bund.de

'Institute of Animal Nutrition, Friedrich-Loeffler-Institute (FLI), Federal Research Institute for Animal Health, Bundesallee 50, 38116, Braunschweig, Germany

Full list of author information is available at the end of the article
}

transduction pathways and in lipid mediators like Prostaglandin $E_{2}$ [7]. CLA supplementation e.g. led to decreased lymphocyte activation of healthy men [8] and declined proliferative response in rat splenocytes [9]. Dietary CLA are capable to change the FA profile of human peripheral blood mononuclear cells (PBMC), but did not alter their function, like the mitogen stimulated production of $\mathrm{PGE}_{2}$, leukotriene $\mathrm{B}_{4}\left(\mathrm{LTB}_{4}\right)$, interleukin (IL)-1 $\beta$, IL-2 and tumor necrosis factor $\alpha$ (TNF- $\alpha$ ) [10].

Although CLA originally occur in dairy cattle, the supplementation of the cows' diet with CLA gains in importance, because it reduces the milk fat content, which is ascribed to the trans-10, cis-12 isomer [11]. The impact of a CLA supplementation on the immune system of dairy cows has been rarely investigated. There was no effect of CLA supplementation on the stimulation index (SI) of PBMC obtained from primiparous lactating cows ex vivo 42 and 105 days post partum (pp). But the SI of splenocytes from the same animals were decreased

\section{Biomed Central}


following CLA supplementation [12]. It is unknown, if the effects are similar in pluriparous cows and over a longer supplementation period and if the supplementation changes the FA profile of immune cells, which might have further downstream effects. Therefore, in the present investigation the effects of a long term CLA supplementation were evaluated. In the study primiparous and pluriparous cows were involved. Effects on immune cells were evaluated by cell proliferation assays using PBMC and furthermore, the FA profile of PBMC was analyzed.

\section{Results}

Data concerning performance of the cows in the present study are reported by Pappritz et al. [13].

\section{Fatty acid profile of PBMC}

The main FA occurring in PBMC were C18:0 (stearic acid), C16:0 (palmitic acid), cis-9 C18:1 (oleic acid), cis-9, cis-12 C18:2 (linoleic acid) and cis-5, cis-8, cis-11, cis14 C20:4 (arachidonic acid) (Table 1). CLA supplementation did not change the proportions of these FA significantly, but there was a tendency of increasing C16:0 when CLA was supplemented. Furthermore the proportion of saturated, monounsaturated and polyunsaturated FA as well as the sum of n-3 and n- 6 FA were not influenced by CLA supplementation. Regarding CLA, no trans-10, cis-12 was found in PBMC of control animals, but the isomer significantly increased in both supplemented groups (Table 1). The effect was not seen for the other main supplemented isomer cis-9,trans-11, where no differences were observed between the 3 groups. Other CLA were significantly more frequently found in CON and CLA-50 group than in CLA-100 group. When all CLA isomers are considered together there were no differences among the groups. Furthermore, CLA supplementation did influence the proportion of trans9 C18:1 and cis-15 C24:1 (Table 1). Both FA were significantly reduced in CLA-100 group compared to CON.

\section{Ex vivo cell proliferation assay}

Cell viability and mitogen stimulated proliferation of PBMC was evaluated 7, 21, 35, 49, 105 and 182 days pp by Alamar blue (AB) and MTT assay.

There was no effect of supplementation ( $p=0.742$ in MTT assay, $\mathrm{p}=0.955$ in AB assay) and lactation number ( $\mathrm{p}=0.487$ in MTT assay and $\mathrm{p}=0.972$ in $\mathrm{AB}$ assay) on the stimulation index (SI) of PBMC. Furthermore, no interactions between day of lactation and lactation number $(\mathrm{p}=0.948$ in MTT assay and $\mathrm{p}=0.861$ in AB assay), supplementation and lactation number $(p=0.702$ in MTT assay and $p=0.792$ in AB assay) as well as supplementation and day of lactation ( $\mathrm{p}=0.821$ in MTT assay and $\mathrm{p}=0.128$ in $\mathrm{AB}$ assay) were found. Only the day of lactation had a significant effect $(\mathrm{p}<0.001$ in both assays, Figure 1). At d 49 pp the SI reached the minimum in both assays. In the $A B$ assay the SI was rising from d 7 to $\mathrm{d} 35 \mathrm{pp}$ and in contrast the SI decreased from d 7 pp until d 49 pp in the MTT assay.

The SI $105 \mathrm{~d}$ pp was not correlated with the proportion of cis-9, trans-11 CLA, trans-10, cis-12 CLA, other CLA isomers or the sum of all CLA isomers in both assays.

\section{Discussion}

The FA profile of immune cells is influenced by FA in the diet, thus it is possible to modify the FA profile of these cells by altering the consumption of certain FA [7]. This effect is described for $n-3$ polyunsaturated FA (PUFA) from fish oil or preparations of eicosapentaenoic acid or docosahexaenoic acid [14-16], but also for CLA [10] in humans. The altered FA profile of the total lipids and phospholipids, respectively, might cause changes in the function of the cells, indicated by effecting signaling pathways or the pattern of lipid mediator production [7]. Most studies were performed with humans, but also effects of certain FA on immune cell functions in dairy cows have been reported $[17,18]$. In these studies the effects on FA profile of bovine immune cells were not investigated [19].

In the present study the proportion of CLA in the lipid fraction of PBMC was low (less than 1\% of all fatty acid methyl esters [FAME]). Due to CLA supplementation the proportion of trans-10, cis-12 CLA was increased, but the cis-9, trans-11 isomer remained unchanged. The trans-10, cis-12 isomer was not found in PBMC of the control group and it accounted for only $0.004 \%$ of total FAME in the milk fat of the same animals [13]. The cis9, trans-11 isomer is the major CLA isomer occurring in dairy products. It is formed in the rumen by microbial fermentation [1] and by endogenous synthesis via $\Delta^{9}$ desaturase in the mammary gland [2]. These sources might have a greater impact on the proportion of cis-9, trans-11 CLA in bovine PBMC than the supplementation. There was also no effect of the diet on the percentage of cis-9, trans-11 in the milk fat of the same animals [13]. In humans, the proportion of CLA in PBMC was increased after $63 \mathrm{~d}$ CLA supplementation $(3.9 \mathrm{~g} / \mathrm{d}$ of CLA isomers). The cis-9, trans-11 isomer increased from 0.05 to $0.16 \%$ of all analyzed FA, which is in the same range as the proportion in bovine PBMC in the present study. The trans-10, cis-12 isomer increased from $0.04 \%$ to $0.19 \%$ [10], which is much higher than in the present study. In humans, the main source of CLA is the consumption of dairy products and ruminant meat [20], but the endogenous synthesis via $\Delta^{9}$-desaturase is also observed in humans, whereby trans-11 C18:1 serves as a precursor $[21,22]$. 
Table 1 Fatty acid profile of peripheral blood mononuclear cells

\begin{tabular}{|c|c|c|c|c|c|c|c|}
\hline \multirow{3}{*}{$\begin{array}{l}\text { Fatty acid } \\
\text { C16:0 }\end{array}$} & \multicolumn{6}{|c|}{ Group } & \multirow{3}{*}{$\begin{array}{l}\text { Probability } \\
0.061\end{array}$} \\
\hline & \multicolumn{2}{|c|}{ CON } & \multicolumn{2}{|c|}{ CLA-50 } & \multicolumn{2}{|c|}{ CLA-100 } & \\
\hline & 15.30 & \pm 0.58 & 16.29 & \pm 0.41 & 17.12 & \pm 0.57 & \\
\hline C18:0 & 26.81 & \pm 1.02 & 27.53 & \pm 0.82 & 28.18 & \pm 0.75 & 0.532 \\
\hline C18:1C9 & 13.52 & \pm 0.51 & 12.94 & \pm 0.54 & 12.46 & \pm 0.46 & 0.333 \\
\hline $\mathrm{C} 18: 1 \mathrm{C11}$ & 2.41 & \pm 0.13 & 2.25 & \pm 0.11 & 2.19 & \pm 0.08 & 0.338 \\
\hline C18:1 t9 & 0.27 & $\pm 0.01^{a}$ & 0.23 & $\pm 0.01^{\mathrm{ab}}$ & 0.22 & $\pm 0.01^{b}$ & 0.017 \\
\hline $\mathrm{C} 18: 2 \mathrm{C} 9, \mathrm{C} 12$ & 10.13 & \pm 0.23 & 11.07 & \pm 0.35 & 10.36 & \pm 0.27 & 0.072 \\
\hline CLA-c9,t11 & 0.17 & \pm 0.01 & 0.16 & \pm 0.01 & 0.15 & \pm 0.01 & 0.071 \\
\hline CLA-t10,c12 & 0.00 & $\pm 0.00^{\mathrm{a}}$ & 0.01 & $\pm 0.00^{b}$ & 0.02 & $\pm 0.00^{b}$ & $<0.001$ \\
\hline other CLA & 0.07 & $\pm 0.01^{\mathrm{a}}$ & 0.06 & $\pm 0.01^{a}$ & 0.03 & $\pm 0.01^{b}$ & 0.006 \\
\hline$C 20: 3 n-6$ & 3.06 & \pm 0.14 & 3.07 & \pm 0.13 & 2.95 & \pm 0.16 & 0.805 \\
\hline$C 20: 4 n-6$ & 11.12 & \pm 0.42 & 9.92 & \pm 0.49 & 9.96 & \pm 0.65 & 0.214 \\
\hline$C 20: 5 n-3$ & 1.03 & \pm 0.08 & 0.96 & \pm 0.06 & 0.94 & \pm 0.05 & 0.553 \\
\hline$C 22: 4 n-6$ & 1.35 & \pm 0.07 & 1.29 & \pm 0.08 & 1.27 & \pm 0.10 & 0.791 \\
\hline C22:5n-3 & 4.11 & \pm 0.29 & 4.03 & \pm 0.44 & 4.05 & \pm 0.22 & 0.295 \\
\hline C24:1 C15 & 0.03 & $\pm 0.01^{\mathrm{a}}$ & 0.02 & $\pm 0.01^{\mathrm{ab}}$ & 0.01 & $\pm 0.00^{\mathrm{b}}$ & 0.03 \\
\hline Minor $\mathrm{FA}^{+}$ & 11.94 & \pm 0.61 & 11.39 & \pm 0.42 & 11.27 & \pm 0.30 & 0.547 \\
\hline SFA & 46.39 & \pm 1.48 & 48.09 & \pm 1.22 & 49.73 & \pm 1.28 & 0.214 \\
\hline MUFA & 20.80 & \pm 0.691 & 19.78 & \pm 0.73 & 18.95 & \pm 0.48 & 0.131 \\
\hline PUFA & 32.81 & \pm 1.00 & 32.12 & \pm 0.90 & 31.32 & \pm 1.09 & 0.576 \\
\hline all C18:1 trans-FA & 2.53 & \pm 0.11 & 2.34 & \pm 0.13 & 2.28 & \pm 0.13 & 0.346 \\
\hline all CLA & 0.24 & \pm 0.01 & 0.23 & \pm 0.02 & 0.20 & \pm 0.01 & 0.071 \\
\hline all n-3 FA & 6.37 & \pm 0.41 & 6.01 & \pm 0.42 & 6.10 & \pm 0.24 & 0.772 \\
\hline all n-6 FA & 26.30 & \pm 0.71 & 25.98 & \pm 0.81 & 25.12 & \pm 1.00 & 0.602 \\
\hline$n-3 / n-6$ & 0.24 & \pm 0.01 & 0.24 & \pm 0.02 & 0.25 & \pm 0.02 & 0.872 \\
\hline MC-FA (C10 > C14) & 0.53 & \pm 0.07 & 0.68 & \pm 0.10 & 0.87 & \pm 0.17 & 0.176 \\
\hline
\end{tabular}

Fatty acid profile of peripheral blood mononuclear cells from cows that received a control fat preparation (CON, $\mathrm{n}=15)$ or $50 \mathrm{~g} / \mathrm{d}(\mathrm{CLA}-50, \mathrm{n}=15)$ and $100 \mathrm{~g} / \mathrm{d}$ (CLA-100, $n=16)$ of a CLA supplement. Blood samples were taken after 70 and 140 days of supplementation and samples were pooled for each cow. Results are expressed as $\%$ of total fatty acid methyl esters, means \pm standard error. $p<0.1$ in italics and indicate tendencies. $p<0.05$ in bold and indicate significant differences, ab: different letters within a row indicate significant differences, $p<0.05$, Tukey test.

${ }^{\dagger}$ Minor FA contain fatty acids which concentration is less than $1 \%$ of all fatty acids except CLA.

*includes CLA.

$c=$ cis, $t=$ trans, SFA = saturated fatty acids, MUFA = monounsaturated fatty acids, PUFA = polyunsaturated fatty acids, MC-FA = medium chain fatty acid.

The two predominant FA in the lipid fraction of PBMC were C18:0 and C16:0 in the present study. That is in line with results from Contreras et al. [19] who investigated the FA composition of the phospholipid fraction of PBMC in dairy cows around parturition. In the present study, the major FA of the lipid fraction of PBMC were not significantly affected by CLA supplementation, but there was a trend of increased C16:0 following CLA supplementation. The increased percentage of C16:0 was also found in the FA profile of erythrocytes from new born calves whose mothers received the CLA supplement during a certain time of pregnancy [23]. Reasons for this effect are not clarified yet. CLA, particularly the trans-10, cis-12 isomer, down regulate the expression of $\Delta^{9}$-desaturase $[24,25]$ and inhibit its activity [26] in different tissues. Therefore, a slight inhibition of $\Delta^{9}$-desaturase might be accountable for the increased proportion of C16:0. Two minor FA $(<1 \%$ of total FAME), trans-9 C18:1 (elaidic acid) and cis-15 C24:1 (nervonic acid), were affected by CLA supplementation. Their percentage was decreased in CLA100 group. Nervonic acid is an important FA in myelin sphingolipids [27] and therefore in the nervous system. Elaidic acid is, like other trans C:18:1 FA, mainly found in partially hydrogenated vegetable oils, but also in fat of dairy products [28]. In splenocytes obtained from rats, elaidic acid was only found in phosphatidylethanolamine and phosphatidylcholine, when elaidic acid was supplemented. In this study the elaidic acid supplementation caused increased mitogen stimulated production of interleukin-6 [29].

The mitogen stimulated proliferation was investigated to obtain information about the functionality of PBMC. The function of the cells was not influenced by the CLA 

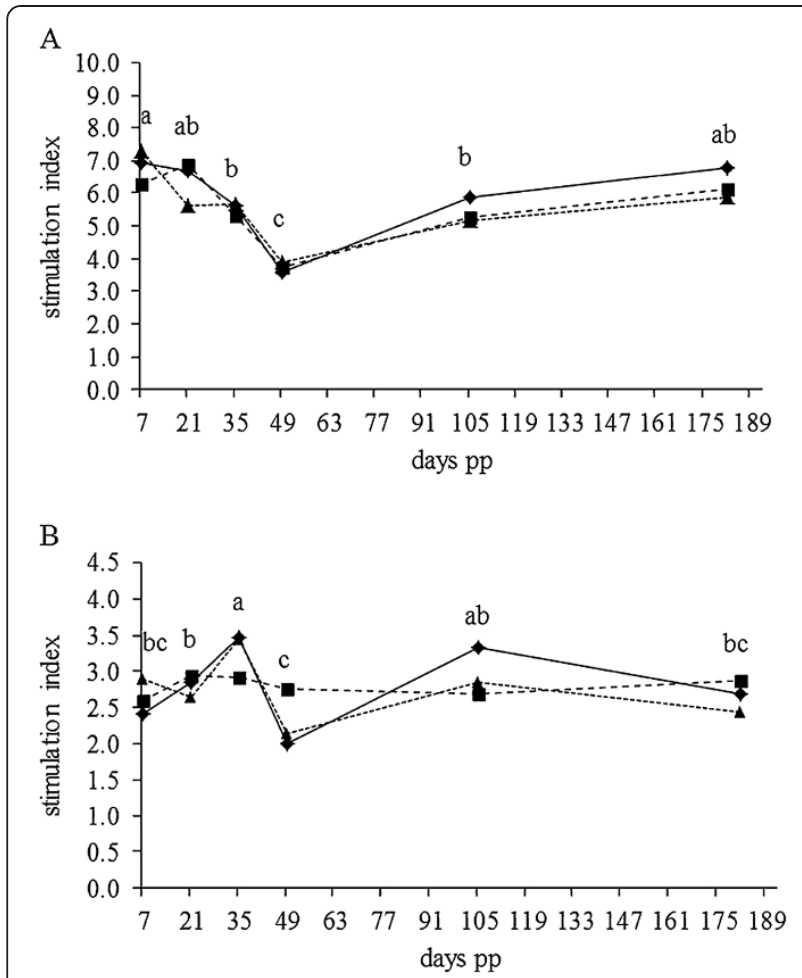

Figure 1 Stimulation index of peripheral blood mononuclear cells in MTT (A) and Alamar blue assay (B). Cows were supplemented with a control fat preparation $(C O N, n=15)$ or $50 \mathrm{~g} / \mathrm{d}$ of a CLA supplement (CLA-50, $n=15$ ) or $100 \mathrm{~g} / \mathrm{d}$ of a CLA supplement (CLA-100, $n=16)$, abc: indicates significant differences between sampling days, $p<0.05$.

supplementation, although the fatty acid composition was slightly altered in the present study. Also the milk fat depression was observed in the present study. The milk fat content was reduced dose dependently by $7 \%$ and $12 \%$ in CLA-50 and CLA-100 group, respectively, in the time period from 49 to $182 \mathrm{~d}$ pp [13]. Changes in the SI were observed over the lactation period. It is known that the immune system of dairy cattle is suppressed after calving [30], which was e. g. demonstrated by a decreased SI of ConA stimulated PBMC ex vivo [12]. As a reason for the immunosuppression in the pp period increased non esterified fatty acids (NEFA) concentrations, which result from increasing fat mobilization, are discussed. NEFA inhibit proliferation of bovine PBMC in vitro [31]. The immunosuppressive effect in the pp period was not observed in the MTT assay of the present study, although NEFA concentrations in plasma were much higher from 7 to $49 \mathrm{~d}$ pp $(0.70,0.66$ and $0.69 \mathrm{mmol} / \mathrm{L}$ in CON, CLA-50 and CLA100 group, respectively) than between $\mathrm{d} 49$ and $182 \mathrm{pp}$ $(0.29,0.25,0.22 \mathrm{mmol} / \mathrm{L}$ in CON, CLA-50 and CLA-100 group, respectively) [13]. In the $\mathrm{AB}$ assay the $\mathrm{SI}$ increased from $\mathrm{d} 7$ to $35 \mathrm{pp}$, but reached the minimum at d $49 \mathrm{pp}$ like in the MTT assay. At that time point the cows of the CLA fed groups turned from negative to positive calculated energy balance. Until $49 \mathrm{~d}$ pp the cows of the CON group were not in negative calculated energy balance $(14.9 \pm 5.4 \mathrm{MJ} / \mathrm{d})$, whereas the calculated energy balance of the CLA fed cows was negative during that period (CLA-50 - $12.3 \pm 5.4 \mathrm{MJ} / \mathrm{d}$ and CLA-100 $-8.3 \pm 5.2 \mathrm{MJ} /$ d). These differences are based on a lower dry matter (DM) intake in CLA supplemented groups during the first weeks of lactation (CON $21.1 \pm 0.7 \mathrm{~kg} / \mathrm{d}$, CLA-50 $18.5 \pm 0.7 \mathrm{~kg} / \mathrm{d}$ and CLA-100 $17.8 \pm 0.7 \mathrm{~kg} / \mathrm{d}$ ). In the following period (until the end of the supplementation $182 \mathrm{~d} \mathrm{pp}$ ), no differences between the feeding groups occurred in DM intake $($ CON $21.6 \pm 0.6 \mathrm{~kg} / \mathrm{d}$, CLA-50 $22.4 \pm 0.6 \mathrm{~kg} / \mathrm{d}$ and CLA-100 21.2 $\pm 0.6 \mathrm{~kg} /$ ) and energy balance (CON $15.3 \pm 2.7 \mathrm{MJ} / \mathrm{d}, \mathrm{CLA}-5010.4 \pm 2.6 \mathrm{MJ} / \mathrm{d}$ and CLA-100 $10.8 \pm 2.5 \mathrm{MJ} / \mathrm{d}$ ) [13]. The differences between $\mathrm{AB}$ and MTT assay might be due to different enzyme systems involved in reduction of the respective dye. MTT is mainly reduced by mitochondrial and microsomal enzymes and $\mathrm{AB}$ by mitochondrial and cytosolic enzymes [32].

Hussen et al. [33] examined the leukocyte profile of PBMC of the present investigation due to CLA supplementation. Although the SI of PBMC was not influenced by CLA supplementation, there were effects on their composition. The percentage of $\mathrm{CD} 4+$ cells was decreased from $21 \mathrm{~d}$ pp onwards in the CLA-100 group compared to control and CLA-50 group and CD8+ cells were slightly increased, starting $21 \mathrm{~d}$ pp. The percentage of monocytes, B-cells and $\gamma \delta$-T cells was not altered by the diet. Furthermore, IgG1 and IgG2 levels in serum were significantly lower in the CLA-100 group throughout the supplementation period.

It is interesting to note that PBMC of calves (5 calves per group) of the CLA fed cows investigated in the present experiment showed an effect of the diet in the MTT assay (SI in CON 3.6 \pm 1.0 , CLA-50 1.6 \pm 0.7 , CLA$1004.3 \pm 0.8$ ), but not in the $A B$ assay on mitogenic response immediately after partus and 1 day post natum. However, at this time, when CLA supplementation was no longer fed, the cows still did not exhibit differences in the mitogen stimulated response of PBMC, but the SI was increasing from $\mathrm{d} 0$ to $\mathrm{d} 21 \mathrm{pp}$ in all groups [23].

In most studies investigating the effect of CLA on immune function, the FA profiles of the investigated cells were not analyzed. Altogether, the effects of CLA supplementation to dairy cows are low and effects seen in other species, e.g. [34,35], could not be observed.

\section{Conclusions}

Long term CLA supplementation to dairy cows did not alter the mitogen-induced proliferation of PBMC ex vivo, although the trans-10,cis-12 CLA isomer was increased in the lipid fraction of PBMC. Further 
investigations are necessary to evaluate if the increased proportion of trans-10 cis-12 CLA in the lipid fraction of $\mathrm{PBMC}$ has an impact on other immunological parameters.

\section{Materials and methods Experimental design}

The experiment was carried out at the experimental station of the Friedrich-Loeffler-Institute (FLI) in Braunschweig, Germany. The study was conducted according to the European Community regulations concerning the protection of experimental animals and the guidelines of the LAVES (Lower Saxony State Office for Consumer Protection and Food Safety, Oldenburg, Germany, File number 33.14.42502-04-071/07). In the study 46 cows, 32 pluriparous and 14 primiparous, were assigned to 3 feeding groups. The control group $(\mathrm{CON}, \mathrm{n}=15$, out of them 5 primiparous cows) received $100 \mathrm{~g} / \mathrm{d}$ of a control fat preparation, the CLA-50 group ( $n=15$, out of them 4 primiparous cows) received $50 \mathrm{~g} / \mathrm{d}$ of the control fat preparation and the CLA supplement, respectively, and the CLA-100 group $(n=16$, out of them 5 primiparous cows) received $100 \mathrm{~g} / \mathrm{d}$ of the CLA supplement. The supplementation period began one day pp and lasted for 182 days. During that time the cows were fed a partial mixed ration (PMR) containing 37\% concentrate and $63 \%$ silage (60\% maize silage, $40 \%$ grass silage based on DM content) for ad libitum consumption by a computerized feeding station (Type RIC, Insentec, B.V., Marknesse, The Netherlands). The control fat preparation (Silafat ${ }^{\circledR}$, BASF SE, Ludwigshafen, Germany) and the CLA supplement (Lutrell ${ }^{\circledR}$ pure, BASF SE, Ludwigshafen, Germany) were given with $4 \mathrm{~kg}$ additional concentrate, also via a computerized concentrate feeding station. The CLA supplement contained mainly the cis9,trans-11 and the trans-10, cis-12 isomer $(12.0 \%$ and $11.9 \%$ of FAME, respectively). The daily consumption of each isomer was $4 \mathrm{~g} / \mathrm{d}$ in the CLA-50 group and $8 \mathrm{~g} / \mathrm{d}$ in the CLA-100 group. In the control fat preparation CLA was substituted by stearic acid, which is also the main FA in the CLA supplement. Water was offered for ad libitum consumption. More detailed information about the animal experiment, including the FA profile of the supplements, is reported elsewhere [13].

\section{Sample preparation}

At day 7, 21, 35, 49, 70, 105, 140 and 182 pp blood $(30 \mathrm{~mL})$ was taken by jugular venipuncture into heparinized vacutainer tubes. PBMC were isolated from whole-blood by density gradient centrifugation using Biocoll (Biochrom AG, Berlin, Germany, L 6115). The samples were processed as described by Renner et al. [36]. Samples of day 7, 21, 35, 49, 105 and 182 pp were used to perform cell proliferation assays. The other 2 samples (70 and $140 \mathrm{~d}$ pp) were pooled for each cow and the FA profile of PBMC was analyzed. All samples were frozen and stored at $-80^{\circ} \mathrm{C}$ in freezing medium containing fetal bovine serum (FBS, Biochrom AG, Berlin, Germany, S 0615) and 10\% dimethyl sulfoxide (DMSO, Sigma-Aldrich, Steinheim, Germany, D 2438).

\section{Analysis of fatty acid profile}

The PBMC were washed 3 times with saline to remove freezing medium. Cellular lipids were extracted according to the procedure described by Bligh and Dyer [37] using a methanol/chloroform mixture. The extracted lipids were then transesterificated with Boron trifluoride $\left(\mathrm{BF}_{3}\right)$ to produce FAME, followed by a purification of the extracts using thin-layer chromatography (SIL G-25 $\mathrm{UV}_{254}$, Macherey-Nagel, Dueren, Germany). FAME were analyzed by gas chromatography ([GC], GC-17A Version 3, Schimadzu, Kyoto, Japan), fitted with an auto sampler and flame ionization detector. Two different procedures were necessary to identify all FAME and were conducted according to Degen et al. [38]. The general FA profile (FA, whose carbon length is 4 to 25 ) was analyzed using a medium polarity column (DB-225 ms, $60 \mathrm{~m} \times$ $0.25 \mathrm{~mm}$ inner diameter; $0.25 \mu \mathrm{m}$ film thickness; Agilent Technologies, Santa Clara, USA). Furthermore, the cis and trans isomers of C18:1 were separated via a high polarity column (Select ${ }^{\mathrm{TM}}$ FAME, $200 \mathrm{~m} \mathrm{x} 0.25 \mathrm{~mm}$ inner diameter, $0.25 \mu \mathrm{m}$ film thickness; Agilent Technologies, Santa Clara, USA). The following reference standards were used as FAME mix to identify FA peaks: No. 463, 674, (Nu-Chek Prep, Inc., Elysian, USA), BR2, BR4, ME 93 (Larodan; Malmö, Sweden), Supelco ${ }^{\circledR} 37$ Component FAME Mix, PUFA No. 3, conjugated linoleic acid, linoleic-, linolenic- and octadecenoic acid methyl ester mix (Supelco; Bellefonte, USA). Results are expressed as percentage of total FAME.

\section{Cell proliferation assays}

PBMC viability and concanavalin A (ConA, SigmaAldrich, Steinheim, Germany, C 5275) stimulated proliferation were analyzed by MTT (3-(4,5-dimethylthiazol-2-yl)-2,5-diphenyl-tetrazolium bromide) and Alamar blue (AB) assay. The procedures were carried out as described in detail elsewhere [12].

\section{Calculations and statistics}

Statistical analyses of the FA profile were performed by a one factorial analysis of variance (ANOVA) using the Statistica 8 for the Windows operating system, followed by a Tukey test. Probabilities below 0.05 were considered as statistically significant and $\mathrm{p}<0.1$ as a tendency.

The stimulation index (SI) was calculated by the following equation for the MTT assay: 
SI = optical density (OD) of ConA stimulated PBMC/ $\mathrm{OD}$ of non-stimulated PBMC

In the $\mathrm{AB}$ assay fluorescence instead of $\mathrm{OD}$ was used.

The PROC MIXED procedure with a compound symmetry covariance structure and supplementation, day of lactation and lactation number (primiparous vs pluriparous) as fixed factors as well as interactions of these factors was performed for statistical analyses of the SI using SAS (Software package, Version 9.1, SAS Institute, Cary, NC, USA). Because of frequent measurements during the experiment and the resulting individual cow effects, they were considered by the repeated procedure.

Correlations between the proportion of CLA isomers and the SI at $105 \mathrm{~d}$ pp were calculated using Statistica 8.

\section{Abbreviations}

AB: Alamar blue; ANOVA: analysis of variance; CLA: conjugated linoleic acid; CON: control group; ConA: concanavalin A; DM: dry matter; FA: fatty acid; NEFA: non esterified fatty acids; OD: optical density; PBMC: peripheral blood mononuclear cells; PUFA: polyunsaturated fatty acids; pp: post partum; SI: stimulation index

\section{Competing interests}

The authors declare that they have no competing interests.

\section{Authors' contributions}

LR performed isolation of PBMC and cell proliferation assays, did statistical analysis, participated in study design and wrote the manuscript. JP carried out the animal study. RK performed fatty acid analysis of PBMC. SK helped with the statistical analysis and to draft the manuscript. GJ participated in study design and fatty acid analysis. SD participated in study design, helped with statistical analysis and to draft the manuscript. All authors read and approved the final manuscript.

\section{Acknowledgement}

The authors would like to thank the Deutsche Forschungsgemeinschaft, who financially supported the work (PAK 286/1, DA558/5-1, WP 7).

The authors have declared no conflict of interest.

\section{Author details}

${ }^{1}$ Institute of Animal Nutrition, Friedrich-Loeffler-Institute (FLI), Federal Research Institute for Animal Health, Bundesallee 50, 38116, Braunschweig, Germany. ${ }^{2}$ Institute of Nutrition, Friedrich Schiller University Jena, Jena, Germany.

\section{Received: 19 March 2012 Accepted: 27 April 2012}

Published: 5 June 2012

\section{References}

1. Kepler CR, Hirons KP, MCNeill JJ, Tove SB: Intermediates and products of the biohydrogenation of linoleic acid by Butyrinvibrio fibrisolvens. J Biol Chem 1966, 241:1350-1354.

2. Griinari JM, Corl BA, Lacy SH, Chouinard PY, Nurmela KW, Bauman DE: Conjugated linoleic acid is synthesized endogenously in lactating dairy cows by Delta(9)-desaturase. J Nutr 2000, 130:2285-2291.

3. Lee KW, Lee HJ, Cho HY, Kim YJ: Role of the conjugated linoleic acid in the prevention of cancer. Crit rev Food Sci Nutr 2005, 45:135-144.

4. Bhattacharya A, Banu J, Rahman M, Causey J, Fernandes G: Biological effects of conjugated linoleic acids in health and disease. J Nutr Biochem 2006, 17:789-810

5. Lee KN, Kritchevsky D, Pariza MW: Conjugated linoleic-acid and atherosclerosis in rabbits. Atherosclerosis 1994, 108:19-25.

6. O'Shea M, Bassaganya-Riera J, Mohede ICM: Immunomodulatory properties of conjugated linoleic acid. Am J Clin Nutr 2004, 79:1199S-1206S
7. Calder PC: The relationship between the fatty acid composition of immune cells and their function. Prostaglandins Leukot Essent Fatty Acids 2008, 79:101-108.

8. Tricon S, Burdge GC, Kew S, Banerjee T, Russell JJ, Grimble RF, Williams CM, Calder PC, Yaqoob P: Effects of cis-9, trans-11 and trans-1 0, cis-12 conjugated linoleic acid on immune cell function in healthy humans. Am J Clin Nutr 2004, 80:1626-1633.

9. Ramirez-Santana C, Castellote C, Castell M, Rivero M, Rodriguez-Palmero M, Franch A, Perez-Cano FJ: Long-term feeding of the cis-9, trans-11 isomer of conjugated linoleic acid reinforces the specific immune response in rats. J Nutr 2009, 139:76-81.

10. Kelley DS, Simon VA, Taylor PC, Rudolph IL, Benito P, Nelson GJ, Mackey BE, Erickson KL: Dietary supplementation with conjugated linoleic acid increased its concentration in human peripheral blood mononuclear cells, but did not alter their function. Lipids 2001, 36:669-674.

11. Baumgard LH, Corl BA, Dwyer DA, Saebo A, Bauman DE: Identification of the conjugated linoleic acid isomer that inhibits milk fat synthesis. Am J Physiol-Reg / 2000, 278:R179-R184.

12. Renner $L$, von Soosten $D$, Sipka $A$, Döll S, Beineke $A$, Schuberth HJ, Dänicke S: Effect of trans-10, cis-12 and cis-9, trans-11 conjugated linoleic acid (CLA) on proliferation and cytokine expression of bovine PBMC and splenocytes ex vivo. Arch Anim Nutr 2012, 66:73-85.

13. Pappritz J, Meyer U, Kramer R, Weber EM, Jahreis G, Rehage J, Flachowsky G, Dänicke S: Effects of long-term supplementation of dairy cow diets with rumen-protected conjugated linoleic acids (CLA) on performance, metabolic parameters and fatty acid profile in milk fat. Arch Anim Nutr 2011, 65:89-107.

14. Thies F, Nebe-von-Caron G, Powell JR, Yaqoob P, Newsholme EA, Calder PC: Dietary supplementation with gamma-linolenic acid or fish oil decreases T lymphocyte proliferation in healthy older humans. J Nutr 2001, 131:918-1927.

15. Rees D, Miles EA, Banerjee T, Wells SJ, Roynette CE, Wahle KWJ, Calder PC: Dose-related effects of eicosapentaenoic acid on innate immune function in healthy humans: a comparison of young and older men. Am J Clin Nutr 2006, 83:331-342.

16. Kew S, Mesa MD, Tricon S, Buckley R, Minihane AM, Yaqoob P: Effects of oils rich in eicosapentaenoic and docosahexaenoic acids on immune cell composition and function in healthy humans. Am J Clin Nutr 2004 79:674-681.

17. Lessard M, Gagnon N, Godson DL, Petit HV: Influence of parturition and diets enriched in $n-3$ or $n-6$ polyunsaturated fatty acids on immune response of dairy cows during the transition period. J Dairy Sci 2004, 87:2197-2210

18. Lessard M, Gagnon N, Petit HV: Immune response of postpartum dairy cows fed flaxseed. J Dairy Sci 2003, 86:2647-2657.

19. Contreras GA, O'Boyle NJ, Herdt TH, Sordillo LM: Lipomobilization in periparturient dairy cows influences the composition of plasma nonesterified fatty acids and leukocyte phospholipid fatty acids. J Dairy Sci 2010, 93:2508-2516.

20. Fritsche J, Steinhart H: Amounts of conjugated linoleic acid (CLA) in German foods and evaluation of daily intake. Z Lebensm Unters Forsch AFood Res Technol 1998, 206:77-82.

21. Kuhnt K, Kraft J, Vogelsang H, Eder K, Kratzsch J, Jahreis G: Dietary supplementation with trans-11-and trans-12-18: 1 increases cis-9, trans11-conjugated linoleic acid in human immune cells, but without effects on biomarkers of immune function and inflammation. Brit J Nutr 2007, 97:1196-1205

22. Turpeinen AM, Mutanen M, Aro A, Salminen I, Basu S, Palmquist DL, Griinari $\mathrm{JM}$ : Bioconversion of vaccenic acid to conjugated linoleic acid in humans. Am J Clin Nutr 2002, 76:504-510.

23. Dänicke S, Kowalczyk J, Renner L, Pappritz J, Meyer U, Kramer R, Weber E-M, Döll S, Rehage J, Jahreis G: Long-term effects of rumen-protected conjugated linoleic acids (CLA) fed to dairy cows during early gestation on immunological, hematological and metabolic characteristics of cows and their calves, and on fatty acid profile of milk and erythrocyte lipids. J Dairy Sci. [in press].

24. Baumgard LH, Matitashvili E, Corl BA, Dwyer DA, Bauman DE: trans-10, cis-12 conjugated linoleic acid decreases lipogenic rates and expression of genes involved in milk lipid synthesis in dairy cows. J Dairy Sci 2002, $85: 2155-2163$ 
25. Choi Y, Kim YC, Han YB, Park Y, Pariza MW, Ntambi JM: The trans-10, cis-12 isomer of conjugated linoleic acid downregulates stearoyl-CoA desaturase 1 gene expression in 3 T3-L1 adipocytes. J Nutr 2000, 130:1920-1924.

26. Choi Y, Park Y, Pariza MW, Ntambi JM: Regulation of Stearoyl-CoA Desaturase Activity by the trans-10, cis-12 Isomer of Conjugated Linoleic Acid in HepG2 Cells. Biochem Biophys Res Commun 2001, 284:689-693.

27. Martinez M, Mougan I: Fatty acid composition of human brain phospholipids during normal development. J Neurochem 1998, 71:2528-2533.

28. Pfeuffer $\mathrm{M}$, Schrezenmeir J: Impact of trans fatty acids of ruminant origin compared with those from partially hydrogenated vegetable oils on CHD risk. Int Dairy J 2006, 16:1383-1388.

29. Ruth MR, Wang Y, Yu HM, Goruk S, Reaney MJ, Proctor SD, Vine DF, Field CJ: Vaccenic and elaidic acid modify plasma and splenocyte membrane phospholipids and mitogen-stimulated cytokine production in obese insulin resistant JCR: LA-cp rats. Nutrients 2010, 2:181-197.

30. Nonnecke BJ, Kimura K, Goff JP, Kehrli ME: Effects of the mammary gland on functional capacities of blood mononuclear leukocyte populations from periparturient cows. J Dairy Sci 2003, 86:2359-2368.

31. Lacetera N, Scalia D, Franci O, Bernabucci U, Ronchi B, Nardone A: Short communication: effects of nonesterified fatty acids on lymphocyte function in dairy heifers. J Dairy Sci 2004, 87:1012-1014.

32. Gonzalez RJ, Tarloff JB: Evaluation of hepatic subcellular fractions for Alamar blue and MTT reductase activity. Toxicol in Vitro 2001, 15:257-259.

33. Hussen J, Dänicke S, Schuberth HJ: The effect of a long term dietary supplementation with conjugated linoleic acid (CLA) on the composition of bovine peripheral blood mononuclear cells (PBMC) and the concentration of IgG isotypes in blood and milk. Proc Soc Nutr Physiol 2011, 20:85

34. Nunes EA, Bonatto SJ, de Oliveira HHP, Rivera NLM, Maiorka A, Krabbe EL, Tanhoffer RA, Fernandes LC: The effect of dietary supplementation with 9-cis:12-trans and 10-trans:12-cis conjugated linoleic acid (CLA) for nine months on serum cholesterol, lymphocyte proliferation and polymorphonuclear cells function in Beagle dogs. Res Vet Sci 2008, 84:62-67.

35. Zhang HJ, Guo YM, Yuan JM: Conjugated linoleic acid enhanced the immune function in broiler chicks. Brit J Nutr 2005, 94:746-752.

36. Renner L, Schwabe A, Döll S, Höltershinken M, Dänicke S: Effect of rare earth elements on beef cattle growth performance, blood clinical chemical parameters and mitogen stimulated proliferation of bovine peripheral blood mononuclear cells in vitro and ex vivo. Toxicol Lett 2011, 201:277-284.

37. Bligh EG, Dyer WJ: A rapid method of total lipid extraction and purification. Can J Biochem Physiol 1959, 37:911-917.

38. Degen C, Lochner A, Keller S, Kuhnt K, Dänicke S, Jahreis G: Influence of in vitro supplementation with lipids from conventional and Alpine milk on fatty acid distribution and cell growth of HT-29 cells. Lipids Health Dis 2011, 10:131.

doi:10.1186/1476-511X-11-63

Cite this article as: Renner et al:: Fatty acid profile and proliferation of bovine blood mononuclear cells after conjugated linoleic acid supplementation. Lipids in Health and Disease 2012 11:63.

\section{Submit your next manuscript to BioMed Central and take full advantage of:}

- Convenient online submission

- Thorough peer review

- No space constraints or color figure charges

- Immediate publication on acceptance

- Inclusion in PubMed, CAS, Scopus and Google Scholar

- Research which is freely available for redistribution

Submit your manuscript at www.biomedcentral.com/submit 